\title{
PRICE DISCOVERY AND VOLATILITY TRANSMISSION IN AUSTRALIAN REIT CASH AND FUTURES MARKETS
}

\author{
Ming-Te LEE ${ }^{a}$, Shew-Huei KUO ${ }^{b}$, Ming-Long LEE ${ }^{\text {c, }}$, Chyi Lin LEE d \\ a Department of Accounting, Ming Chuan University, Taipei 111, Taiwan \\ ${ }^{b}$ Department of Finance, National Yunlin University of Science and Technology, Yunlin 64002, Taiwan \\ ${ }^{c}$ Department of Finance, National Dong Hwa University, No. 1, Sec. 2, Da Hsueh Road, Shoufeng, \\ Hualien 97401, Taiwan \\ d School of Business, University of Western Sydney, New South Wales 2751, Australia
}

Received 25 July 2014; accepted 7 May 2015

\begin{abstract}
This study examines the price discovery function and volatility spillovers in Australian real estate investment trust (A-REIT) index futures and also investigates the effects of the global financial crisis (GFC) on these two features. As opposed to the general understanding of the relationship between the cash and the futures markets, the current study finds that the A-REIT cash market led the A-REIT futures market in price discovery and volatility transmission processes before the GFC. However, during the GFC, the two markets interacted bilaterally in terms of information flow, i.e., information flowed in both directions. Furthermore, after the GFC, the futures market followed the cash market again, but less closely. These findings have broad implications for investors in property assets.
\end{abstract}

KEYWORDS: REIT; GFC; Futures; Price discovery; Volatility transmission

\section{INTRODUCTION}

Although recent studies in the real estate markets have highlighted the effectiveness of hedging real estate futures, the links between real estate investment trust (REIT) futures and the underlying REIT market (also known as the cash/spot market) have been largely neglected thus far. The relationship between the futures market and the underlying cash market is a critical issue that has received extensive attention in the stock-index futures literature. The sizable body of literature on mature futures markets has confirmed that stock-index futures typically lead the cash market. However, by contrast with the stock-index futures markets, the Australian REIT (A-REIT) futures market has only recently been established and is considerably smaller than the underlying cash market. Mcmillan and Ulku (2009) noted peculiarities of emerging futures markets regarding investor structure, and several studies, including Bohl et al. (2011), have found that the relationship between the futures and spot markets is strongly affected by the investor structure in these markets. In addition, the A-REIT futures market has changed considerably since the occurrence of the global financial crisis (GFC). Specifically, a sharp increase in the trading volume of A-REIT futures has been experienced since the GFC, which might be attributed to increased hedging activities by institutional investors who are attempting to protect the values of their A-REITs (Newell 2010). Importantly, Xiang et al. (2013) have also documented that a surge in demand for risk-sharing offered by hedgers during the GFC might have attracted more informed speculators into the futures market. Given this possible shift in the investor structure of the A-REIT futures market - which is already distinct from the investor structure of stock futures markets - it is unclear whether findings from the stock futures markets will hold in the REIT market. Thus, research dedicated exclusively to REIT futures is important.

This study aims to fill this research gap by exploring price discovery and volatility transmission in the A-REIT cash and index futures markets. In addition, the impact of the GFC is also investigated.

* Corresponding author. E-mail: ming.long.lee@mail.ndhu.edu.tw 
Specifically, the current study addresses the following questions:

1. Do A-REIT futures prices lead A-REIT cash prices in the short and/or long terms?

2 . Is the volatility of the REIT cash market influenced by developments in the REIT futures market?

3. Did structural changes occur in the processes of price discovery and volatility transmission between the A-REIT cash and futures markets before, during, and after the GFC?

This study makes the following contributions to the literature. First, to the best of our knowledge, this study is the first to attempt to simultaneously explore both price discovery and volatility transmission between a REIT cash market and its futures market. Studies on stock futures markets cannot necessarily be generalised to the REIT market because REIT index futures markets are relatively small compared to stock-index futures markets (Newell, Tan 2004). Therefore, it is essential for property investors to understand the links and interactions between REITs and REIT futures. Specifically, this study will enhance the understanding of the nature of cross-market information flows between A-REITs and A-REIT futures, which is important in facilitating more informed and practical investment decision making regarding the role of A-REIT futures in property fund management. Thus, this study will help fund managers incorporate cross-market links in formulating investment strategies and portfolios. In addition, this study might also help property firms incorporate co-variation in both markets into their hedging strategies. The findings are also expected to help direct property investors improve their investment decision making. If A-REIT futures, which are a relatively new property investment vehicle, provide important information for the property market, direct property investors should incorporate A-REIT futures information into their decision-making processes because direct property tends to incorporate new information into prices more slowly (Geltner et al. 2003).

Second, this study is the first to examine the effects of the GFC on price discovery and volatility transmission between the cash and futures markets for real estate securities simultaneously. The GFC has had a significant impact on the performance of A-REITs. As demonstrated by Figure 1, the performance of A-REITs was extremely volatile during the GFC. The crisis also highlighted the need for institutional investors to employ AREIT futures as a risk-management mechanism to hedge their A-REIT exposure, which has led to dramatic increases in A-REIT futures activity since the GFC. Therefore, the time-varying dynamics of cross-market information flow between A-REITs and A-REIT futures should be closely investigated. Importantly, this study does not merely examine whether there is a structural break in the link between A-REITs and A-REIT futures; instead, our study provides insights into the nature of the structural break itself. Furthermore, few studies have examined the effects of crises on the price discovery functions and volatility spillovers of broad securities index futures. Although Koutmos and Tucker (1996) consider the effects of the October 1987 crash, their study focuses only on the conditional covariance between the S\&P 500

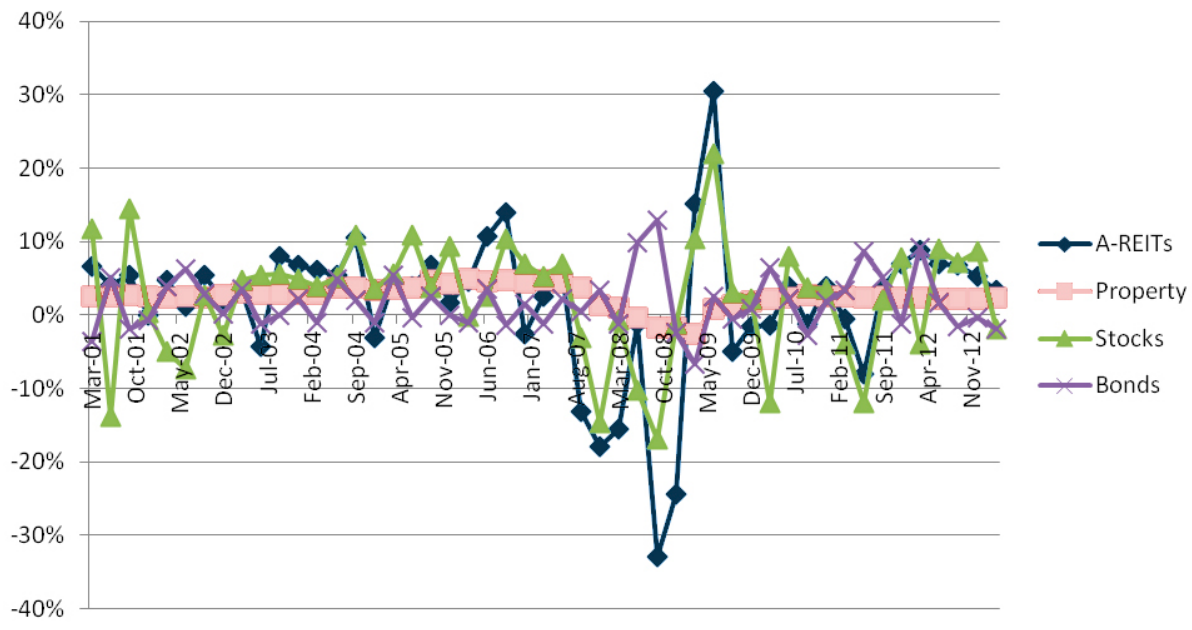

Fig. 1. Total returns of asset classes, quarterly returns, \% (Authors' calculation based on data from IPD Australia and DataStream)

Note: Property returns are smoothed returns. 
index and its futures. Moreover, the effects of financial crises on the price discovery and volatility transmission processes have not been analysed in the real estate cash and futures markets. The current paper fills this gap.

Third, this study is unique because it employs a multivariate error-correction generalised autoregressive conditional heteroscedasticity model with common informational factors (the EC-VARBEKK-GARCH-X model). It is the first real estate study to consider the importance of long-term information when modelling the temporal relationship between the cash and futures prices. This feature further distinguishes our study from previous studies of REIT and real estate securities index futures (Lee 2009; Lee et al. 2014). Specifically, our multivariate EC-VAR(1)-BEKK-GARCH-X(1,1) model incorporates the underlying long-term relationships between A-REITs and A-REIT futures in terms of both conditional means and variances, which allows us to examine for the first time both long- and short-term price discovery and volatility spillovers between A-REITs and A-REIT futures. In this respect, our model also improves on the traditional GARCH model. Therefore, this study provides property investors with further insights regarding the links between A-REITs and A-REIT futures both in the long- and short-term time frames and eliminates the influences of common informational factors to present a clearer picture of the interactions between the A-REIT futures and cash markets that are examined.

The remainder of the paper is organised as follows. Section 2 discusses the significance of AREIT futures. Section 3 reviews related studies in the recent literature. Section 4 describes the A-REIT index and the A-REIT index futures data and presents the empirical methodology. Section 5 discusses the empirical results, and Section 6 concludes the paper.

\section{THE SIGNIFICANCE OF A-REIT FUTURES}

A-REITs have been among the most successful indirect property investment vehicles in Australia. The A-REIT market is the second largest REIT market in the world (Lehman, Roth 2010). In 2012, A-REITs contained more than 2,000 institutionalgrade commercial properties in their portfolios, with total assets worth AUD $\$ 139$ billion (Property Investment Research 2012) and a market capitalisation of more than AUD $\$ 88$ billion (Australian Securities Exchange 2012).

The world's first REIT index futures market was established in 2002, when A-REIT index futures were introduced for trading by the Australian Securities Exchange. Since August 2002, over 1.9 million A-REIT futures contracts have been traded, representing a total value of approximately AUD $\$ 25$ billion, which clearly reflects the significance of A-REIT futures as a risk-management mechanism that enables institutional investors to protect the value of their A-REIT portfolios. Subsequently, markets for futures contracts written on REITs and other types of real estate securities were launched in the United States (2007), Europe (2007), and Japan (2008). Importantly, the establishment of a futures market for A-REITs has enhanced their stature (Newell, Tan 2004).

After its initial establishment period (20022004), the A-REIT futures market has received increasing attention from property investors. As demonstrated in Figure 2, the volume of A-REIT index futures trading has grown steadily since 2005. With the onset of the GFC, however, market risk became the primary concern. During this extremely volatile period, institutional investors (hedgers) increased their demand for risk sharing and were willing to pay higher premiums to protect the value in their REIT portfolios, which made

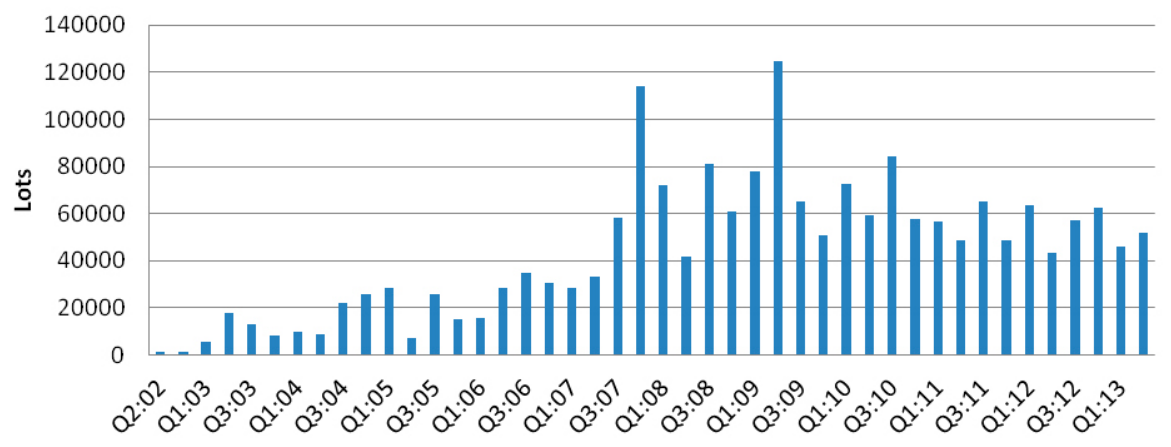

Fig. 2. A-REIT futures quarterly transaction volume: 2002:3-2013:2 (Australian Securities Exchange 2013) 
the REIT futures market attractive to informed speculators. Thus, dramatic increases in the trading volume of A-REIT futures contracts were identified during the GFC. The increasing popularity of A-REIT futures also encourages the participation of informed speculators in the A-REIT futures market.

Thus, a study dedicated to the Australian REIT futures market is notable for a number of reasons. First, the Australian REIT market is the second largest REIT market in the world (Lehman, Roth 2010), and the A-REIT futures market is more established than other real estate futures markets (e.g., even more established than the US real estate futures market) (Newell 2010). Thus, the AREIT market offers a comprehensive dataset with which to examine several issues surrounding REIT futures. Second, the Australian REIT futures market is much smaller than the REIT cash market, and recent studies have found evidence regarding the link between investor structure and the futures price formation process. An investigation of Australian REIT futures should provide further evidence regarding whether a relatively small futures market can enhance the price discovery of its larger cash market. Third, the GFC has had a significant impact on the performance of A-REITs. In addition, significant increases in the trading volumes of A-REIT futures have been documented since the GFC. Thus, an investigation of A-REIT futures might offer further insights into how shifts in investor structure affect their price discovery processes.

\section{LITERATURE REVIEW}

Extensive studies in the real estate markets have examined the explanatory factors of REIT index time-series price behaviours ${ }^{1}$. For instance, employing daily data, Cotter and Stevenson (2007) find that daily US equity REIT behaviour is strongly influenced by the US stock market and

\footnotetext{
${ }^{1}$ There is another line of research that focuses on the cross-sectional individual REIT price behaviours. For instance, Allen, Madura, and Springer (2000) show that REIT-specific factors (leverage, management strategy, and etc.) play some role in explaining the return variance across individual REITs. For brevity, this line of literature is not reviewed because the current study focuses on the time-series price behaviour of REITs. Furthermore, A-REIT futures are written based on an aggregate A-REIT index. Thus, controlling for these cross-sectional individual factors might be a vain exercise.
}

not significantly affected by the US bond market. Using monthly data, Peterson and Hsieh (1997) find that US equity-REIT returns are significantly related to common risk factors in the bond and stock markets, and comparable evidence is found by Chiang et al. (2005) and Chiang et al. (2006). Moreover, Anderson et al. (2005) show that US REITs are significantly linked to smallcap stocks.

Several studies have additionally incorporated direct property factors using quarterly data. For example, Clayton and Mackinnon (2003), Lee et al. (2008), and Lee and Chiang (2010) demonstrate a significant direct property factor in explaining US REIT price behaviour. The general view is that the price behaviour of equity REITs is affected by stock markets in the short run but might have a link to direct properties in the long run (Boudry et al. 2012).

In Australia, Newell (2005) has examined the explanatory factors of A-REIT index time-series price behaviours. In light of A-REIT capitalisation, they utilise the All Ordinaries stock market index ${ }^{2}$ to study the influence of the Australian stock market on A-REIT time-series price behaviour. Employing six-month data, their study indicates that the performance of A-REITs is strongly influenced by the Australian stock and bond markets. However, direct properties have only a marginal influence on A-REIT performance.

In extending this line of research, a large number of studies have examined the interactions among REITs and direct properties (Barkham, Geltner 1995). These interactions are extensively reviewed in Geltner et al. (2003), who find that indirect property (i.e., REITs), in general, tends to incorporate new information into prices faster than direct property. Extensive studies have been devoted to examining the linkages between RE-

\footnotetext{
$\overline{{ }^{2} \text { A-REITs, }}$ unlike REITs in other countries, are large companies instead of small stocks - at least in the Australian investment context. As noted by Goodchild (2008), the A-REIT market is arguably the most developed REIT market globally, contributing 10 percent of the Australian stock index, which is a much larger proportion than is found anywhere else. As of $5^{\text {th }}$ February 2015, eight A-REITs were ranked as the top 50 companies in Australia by market capitalisation. For instance, Westfield Group (\#13), Scentre Group (\#14), Goodman Group (\#22), Stockland (\#23), GPT (\#31), Novion Property (\#35), Mirvac Group (\#37) and Dexus Property Group (\#41). Hence, we included the All Ordinaries Index and did not control for the factor of small capitalisation in our analysis, which further highlights the uniqueness of A-REITs.
} 
ITs and capital assets (Barkham, Geltner 1995; Chiang et al. 2005; Cotter, Stevenson 2006, 2007; Gyourko, Keim 1992; Kallberg et al. 2002; Lee et al. 2008; Liow, Newell 2012; Yang et al. 2012; Yunus et al. 2012). These studies suggest that the linkages among markets are an important topic.

In the finance literature, many studies have been devoted to understanding price discovery and volatility spillovers between the cash and futures markets. These studies have generally found that the futures markets are more informationally efficient than cash markets. In particular, previous research on stocks has used a cointegration method to provide extensive evidence to confirm that futures markets lead cash markets (Pizzi et al. 1998; Ryoo, Smith 2004; Wahab, Lashgari 1993).

Recognising the importance of volatility modelling, Chan et al. (1991) likely represent the first attempt to study short-run price discovery and volatility transmission simultaneously. Their bivariate GARCH model provides strong evidence of a lead from futures to cash returns - and only weak evidence of a lead from cash to futures returns - for the S\&P 500 index. Comparable results are also documented by Koutmos and Tucker (1996) and Tse (1999) in the US. Zhong et al. (2004) use an EC-EGARCH model to incorporate deviations from the long-run price disequilibrium between index and index futures both in conditional means and variances. Their evidence suggests that the Mexican Price and Quotations Index futures market is a useful price discovery vehicle over both the short and long runs. Nevertheless Chan et al. (2004) note that not all stock index futures dominate the process of information transmission.

Recent studies of futures markets have found that investor structure has an impact on the links between the cash and futures markets (Ciner 2006). In particular, the participation of institutional investors improves the contribution of the stock index futures market to price discovery (Bohl et al. 2011). Importantly, comparable results are also found in currency markets in which the futures markets are much smaller than the cash markets (Rosenberg, Traub 2007; Tornell, Yuan 2012; Tse et al. 2006). Cabrera et al. (2009) attributed the leading role of the currency markets in the information transmission processes to the investor structure of these markets. McMillan and Ulku (2009) have also discussed the importance of investor structure in mitigating mispricing in an emerging futures market. Recently Xiang et al. (2013) and Chng and Wang (2014) find that the credit default swap (CDS) market took over price discovery leadership from the equities market during the GFC, which the authors attribute to shifts in investor structure caused by the GFC attracting more informed speculators into the derivatives markets.

However, specific research regarding real estate futures is limited because the markets have only recently been developed, which has led to a dearth of data on such futures. Newell and Tan (2004) is the first empirical study to examine the role of A-REIT futures in protecting the portfolio values of A-REIT investors. Although these authors consider only the early stages of A-REIT futures, they find that A-REIT futures contracts are effective hedging tools. This finding is consistent with the results of Horng and Wei (1999) and Lee (2010), who reveal that US REITs and Australian property funds use derivatives primarily for hedging. Comparable evidence is also found in C. L. Lee and M. L. Lee (2012). More specifically, these authors find that there are risk reduction levels of $45 \%$ and $57 \%$ for Japanese and Australian REITs, respectively, which confirms the previous finding that A-REIT futures are effective hedging instruments. Furthermore, Newell (2010) shows that AREIT futures played an even more significant role during the GFC.

Only two relevant real estate index futures studies examine the links between the cash and futures markets for real estate securities. Lee (2009) examines the determinants of the volatility of A-REIT futures using univariate EGARCH models that show that the A-REIT market has a significant (insignificant) contemporary effect on the volatility (returns) of its A-REIT futures market from December 2004 to December 2008. Lee (2009) thus argues that A-REIT volatility conveys information regarding futures, whereas A-REIT returns do not convey such information.

Lee et al. (2014) also utilise univariate GARCH models to examine the influences of the onset of futures contracts written on the FTSE ERPA/NAREIT Europe and FTSE EPRA/NAREIT Eurozone indices. Their results indicate that futures trading did not destabilise the underlying listed market. Importantly, the results also reveal that the introduction of a futures market has improved the speed and quality of information flow into the cash market. 
However, to date, no study has investigated how a REIT futures market influences its underlying cash market in terms of price discovery and volatility transmission. In addition, no study thus far has examined the effects of financial crises on the price discovery function and volatility spillovers of securities index futures simultaneously.

\section{DATA AND EMPIRICAL MODEL}

\subsection{Data}

This study utilises the daily closing prices of the S\&P/ASX 200 A-REIT index and the S\&P/ASX 200 A-REIT index futures. This study also collects the daily series of the All Ordinaries stock market index and the 10-year or longer Australian government bond index ${ }^{3}$. The data employed in our study span from December 6, 2004 to June 28, 2013 and are based on availability.

Datastream provides the All Ordinaries stock market, the Australian government bond, and the A-REIT index price series. In Australia, four AREIT futures contracts are listed simultaneously, with maturity dates in March, June, September, and December. This study extracts the historical A-REIT futures data from Bloomberg and collects any missing data manually from the Australian Financial Review.

To focus on possible changes in the dynamics of A-REIT cash and futures prices, the full period is divided into three sub-periods: (1) sub-period 1 (the pre-GFC period), which spans from December 6, 2004 to August 9, 2007; (2) sub-period 2 (the GFC period), which covers August 10, 2007 to November 31, 2009; and (3) sub-period 3 (the postGFC period), which runs from December 1, 2009, to June 28,2013 . The literature generally agrees that the approximate starting date of the GFC should be between July and September 2007 and that the GFC had not yet ended by October 2009 (Liow, Newell 2012; Newell 2010). In the current study, the division of the sub-periods primarily follows Newell (2010) ${ }^{4}$.

\footnotetext{
3 The use of the All Ordinaries index and the Australian government bond index are supported by Newell and Acheampong (2001) and Newell (2005), which studied A-REITs.

4 The Augmented Dickey Fuller (ADF) and PhillipPerron (PP) unit root tests show that REIT prices and REIT futures prices are integrated of the first order, i.e., I(1). The Engle-Granger test results also confirmed that the two series are cointegrated over the full sample period and during each sub-period. The results are available from the authors upon request.
}

Table 1 provides information on the sample size and summary statistics for the returns of the S\&P/ ASX 200 A-REIT index, the S\&P/ASX 200 A-REIT index futures, the All Ordinaries stock market index, and the 10-year or longer Australian government bond index. For the full sample period, the bond market has the highest mean return, followed by the market for common stock. The AREIT cash and futures markets have lower mean returns than the bond and stock markets. The ranking clearly reflects the influence of the GFC because the two A-REIT markets also perform worse than the bond and stock markets during the GFC period. After the GFC, there are rebounds in the two A-REIT markets, which clearly perform better than both the contemporaneous bond and stock markets.

The bond market clearly has the lowest return variances in all periods. The A-REIT cash and futures markets have higher variances than the stock market during the GFC period. During the other sub-periods, the three markets have

Table 1. Summary statistics

\begin{tabular}{|c|c|c|c|c|}
\hline \multirow{2}{*}{$\begin{array}{l}\text { Panel A: } \\
\text { Variable }\end{array}$} & \multicolumn{2}{|c|}{ The full period } & \multicolumn{2}{|c|}{$\begin{array}{l}\text { The pre-GFC } \\
\text { period }\end{array}$} \\
\hline & Mean & $\begin{array}{l}\text { Vari- } \\
\text { ance }\end{array}$ & Mean & $\begin{array}{l}\text { Vari- } \\
\text { ance }\end{array}$ \\
\hline $\begin{array}{l}\text { A-REIT cash market } \\
\text { returns }\end{array}$ & -0.026 & 0.026 & 0.041 & 0.008 \\
\hline $\begin{array}{l}\text { A-REIT futures } \\
\text { market returns }\end{array}$ & -0.026 & 0.031 & 0.041 & 0.009 \\
\hline Stock market returns & 0.004 & 0.021 & 0.076 & 0.008 \\
\hline Bond market returns & 0.005 & 0.003 & -0.009 & 0.001 \\
\hline $\begin{array}{l}\text { Number of } \\
\text { observations }\end{array}$ & 2164 & & 675 & \\
\hline Panel B: & $\begin{array}{l}\text { The GF( } \\
\text { period }\end{array}$ & & $\begin{array}{l}\text { The post } \\
\text { period }\end{array}$ & t-GFC \\
\hline Variable & Mean & $\begin{array}{l}\text { Vari- } \\
\text { ance }\end{array}$ & Mean & $\begin{array}{l}\text { Vari- } \\
\text { ance }\end{array}$ \\
\hline A-REIT cash returns & -0.168 & 0.069 & 0.018 & 0.011 \\
\hline $\begin{array}{l}\text { A-REIT futures } \\
\text { returns }\end{array}$ & -0.162 & 0.083 & 0.013 & 0.014 \\
\hline Stock market returns & -0.058 & 0.043 & -0.010 & 0.017 \\
\hline Bond market returns & 0.012 & 0.005 & 0.012 & 0.003 \\
\hline $\begin{array}{l}\text { Number of } \\
\text { observations }\end{array}$ & 587 & & 902 & \\
\hline
\end{tabular}

Notes: The A-REIT cash market return is the differenced logarithm of the S\&P/ASX 200 A-REIT index futures price; the A-REIT futures market return is the differenced logarithm of the underlying S\&P/ASX 200-A-REIT index; the stock market return is the differenced logarithm of the All Ordinaries stock market index; and the bond market return is the differenced logarithm of the 10-year or longer Australian government bond index. The mean returns and variances reported in this table have previously been multiplied by 100 . 
comparable variances. All the markets have their highest variances during the GFC period compared with the other sub-periods. Notably, the two A-REIT markets have clearly larger increases in variances than the stock and bond markets. This pattern indicates that the levels of hedging and speculation are likely to be higher in the A-REIT markets during the GFC period.

\subsection{The empirical model}

Our bivariate empirical investigation uses a vector error-correction model with a bivariate BEKK-GARCH-X $(1,1)$ extension that ensures the condition of a positive semi-definite conditional variance-covariance matrix. The lag-lengths are selected based on the Bayesian information criterion, as suggested by previous studies, such as Liow and Newell (2012). The EC-VAR-BEKK-GARCH-X model consists of two parts, and the mean equations are specified as the following vector errorcorrection equations:

$$
\begin{aligned}
& \Delta c_{t}=\alpha_{c 0}+\alpha_{c 1} \Delta c_{t-1}+\alpha_{c 2} \Delta f_{t-1}+\alpha_{c 3} \Delta s c_{t}+ \\
& \alpha_{c 4} \Delta g b_{t}+\alpha_{c 5} e c t_{t-1}+\varepsilon_{c t} \\
& \Delta f_{t}=\alpha_{f 0}+\alpha_{f 1} \Delta c_{t-1}+\alpha_{f 2} \Delta f_{t-1}+\alpha_{f 3} \Delta s c_{t}+ \\
& \alpha_{f 4} \Delta g b_{t}+\alpha_{f 5} e c t_{t-1}+\varepsilon_{f t}
\end{aligned}
$$

where: $\Delta f_{t}$ is the differenced logarithm of the S\&P/ASX 200-A-REIT index futures price; $\Delta c_{t}$ is the differenced logarithm of the underlying $\mathrm{S} \& \mathrm{P} /$ ASX 200-A-REIT index; $\Delta s c_{t}$ is the differenced logarithm of the All Ordinaries stock market index; $\Delta g b_{t}$ is the differenced logarithm of the 10-year or more Australian government bond index; and $e c t_{t-1}$ is the deviation from long-term equilibrium between the A-REIT futures index and its underlying A-REIT index at time t-1, i.e., $e c t_{\mathrm{t}-1}=f_{\mathrm{t}-1}-\beta_{0}-\beta_{1} c_{\mathrm{t}-1}$.

The inclusion of $\Delta c_{t-1}$ and $\Delta f_{t-1}$ allows for the investigation of short-term price discovery predictions between the A-REIT cash and futures markets. If price discovery occurs in the futures (cash) market, then the short-term prediction hypothesis contends that lagged futures (cash) returns should have significant predictive power for cash (futures) returns over finite forecasting horizons (Zhong et al. 2004). The capital asset pricing model (CAPM) and the previous studies on daily REIT returns call for the inclusion of $\Delta s c_{t}$ and $\Delta g b_{t}$. Specifically, risky asset returns, including those of REIT and REIT futures, are linked to the return of the market portfolio and the risk-free rate in the CAPM framework ${ }^{5}$.

The estimated error-correction term is $e c t_{t-1}$. The long-term prediction hypothesis posits that the error-correction term can predict current changes in cash (futures) prices if price discovery occurs in the futures (cash) market (Yang et al. 2001; Zhong et al. 2004). $\alpha_{f 5}$ and $\alpha_{c 5}$ serve to quantify the relative contributions of each market. Specifically, the magnitudes are inversely related to their contributions. The rationale behind this notion is that the market with a lower adjustment speed coefficient does not follow; instead, this market initiates the mispricing, which implies that the price discovery process occurs primarily in this market.

Furthermore, $\alpha_{f 5}$ is expected to be negative as the result of arbitrage/hedging activities in the futures markets. For example, when the error-correction term is positive and the A-REIT futures are relatively overpriced, A-REIT futures traders have an incentive to sell futures - or a disincentive to buy futures - because the futures price is higher than its long-term equilibrium level, which will cause futures prices to decrease and lead to negative futures returns in the next period. Likewise, when the error-correction term is positive and the A-REIT cash index is relatively underpriced, arbitrage activities should lead to positive cash returns in the next period and imply a positive coefficient for the error-correction term.

However, as noted by Zhong et al. (2004), the A-REIT cash index is not a traded asset but a weighted average of its component A-REITs. Thus, when underpriced, some of these A-REITs may depreciate more steeply because of short-term momentum. As a result, the cash index may deviate even further from equilibrium, implying a negative coefficient for the error-correction term. Therefore, the empirical sign of $\alpha_{c 5}$ depends on the net

\footnotetext{
5 The current study employs daily data. Thus, this study does not include the direct property factor in light of the general viewpoint stated by Boudry et al. (2012), the A-REIT results from Newell (2005), and data unavailability for direct property (normally, on a quarterly basis). Moreover, this study focuses on the time-series behaviour of A-REITs. Therefore, it does not include various REIT-specific factors that are included in cross-sectional studies. Importantly, the variables included in the current study are the same as those of Cotter and Stevenson (2006, 2007), who demonstrated the importance of using daily data in volatility modelling. Nevertheless, these limitations should be borne in mind. In addition, the inclusion of these variables warrants further research.
} 
outcome of the arbitrage and momentum effects (Zhong et al. 2004).

The conditional variance equations of the conditional covariance model can be represented as the following GARCH-X (1,1)-BEKK model:

$$
\begin{aligned}
h_{c c t}= & c_{c c}^{2}+a_{c c}^{2} \varepsilon_{c t-1}^{2}+a_{f c}^{2} \varepsilon_{f t-1}^{2}+2 a_{c c} a_{f c} \varepsilon_{c t-1} \varepsilon_{f t-1}+ \\
& b_{c c}^{2} h_{c c t-1}+b_{f c}^{2} h_{f f t-1}+2 b_{c c} b_{f c} h_{c f t-1}+ \\
& k_{s c c}^{2} s_{t}^{2}+k_{e c c}^{2} e c t_{t-1}^{2} \\
h_{f f t}= & c_{f f}^{2}+a_{f f}^{2} \varepsilon_{f t-1}^{2}+a_{c f}^{2} \varepsilon_{c t-1}^{2}+2 a_{f f} a_{c f} \varepsilon_{f t-1} \varepsilon_{c t-1}+ \\
& b_{f f}^{2} h_{f f t-1}+b_{c f}^{2} h_{c c t-1}+2 b_{f f} b_{c f} h_{f c t-1}+ \\
& k_{s f f}^{2} s_{t}^{2}+k_{e f f}^{2} e c t_{t-1}^{2}
\end{aligned}
$$

where: $\varepsilon_{c t}$ and $\varepsilon_{f t}$ are the unexpected shock series obtained from the mean equations for the cash and futures markets, respectively, and $s_{t}^{2}$ represents the squared standardised innovations of $\Delta s c_{t}$. Specifically, $\Delta s c_{t}$ is regressed on a constant, and the residuals are then divided by the unconditional deviation of the differenced logarithm of the All Ordinaries stock market index to derive $s_{t}$.

In these equations, $a_{f c}$ and $b_{f c}$ measure the short-term volatility spillovers from the REIT futures market to the REIT cash market, and $a_{c f}$ and $b_{c f}$ measure the spillovers moving in the opposite direction (Liow, Newell 2012). More specifically, the $a_{f c}^{2}, b_{f c}^{2}, a_{c f}^{2}$, and $b_{c f}^{2}$ coefficients measure the leadlag relationships in volatilities. The coefficients can be interpreted in terms of information flows that imply the price discovery contributions between the two markets (Chan et al. 1991; Tse 1999).

The inclusion of $s_{t}^{2}$ is intended to account for broad changes in the market. The stock market is used to measure broad changes in the market, and its inclusion is supported by previous REIT studies such as Cotter and Stevenson (2007) and Lee (2009). The justification for the inclusion of $e c t_{t-1}^{2}$ in Equations (3) and (4) is that there may be information asymmetries between the two markets when the index and index futures deviate from their longterm price equilibrium, which could, in turn, influence conditional variances (Zhong et al. 2004). Specifically, changes in trading activities will work to "error-correct" temporary mispricing during events of disequilibria. Such changes are likely to influence volatility in the REIT cash and futures markets. Zhong et al. (2004) refer to this phenomenon as the long-term volatility spillover hypothesis.

In summary, the short-term prediction hypothesis expects a significant coefficient for lagged futures (cash) returns, and the long-term prediction hypothesis anticipates a significant error correc- tion term in the cash (futures) market mean equation. The short-term volatility spillover hypothesis predicts significant cross-market past shock coefficients, and the long-term volatility spillover hypothesis predicts cross-market past variance coefficients in the variance equations. In particular, this study expects that the A-REIT cash market led the A-REIT futures market in the price discovery and volatility transmission processes, given that the literature reveals that REIT futures are primarily used for purposes of hedging. However, the information transmission processes may change as the investor structure changes during and after the GFC.

\section{EMPIRICAL RESULTS}

\subsection{Baseline results on price discovery and volatility transmission}

Table 2 reports the baseline estimates from the full sample period from December 6, 2004 to June 28, 2013. Panel A presents the empirical results of the mean equations. The coefficients of the return interaction terms provide evidence regarding the short-term prediction hypothesis for price discovery. In particular, $\alpha_{c 2}\left(\alpha_{f 1}\right)$ is the estimated effect of lagged futures (cash) returns on cash (futures) returns. Although the t-test cannot reject $H_{0}: \alpha_{c 2}=0$, the test surprisingly rejects $H_{0}: \alpha_{f 1}=0$ at the $1 \%$ significance level, which suggests that A-REIT cash returns have considerable predictive power for A-REIT futures returns but that the reverse is not true. These findings also suggest that short-term price discovery occurs in the cash market but not in the futures market. These results conflict with the general understanding of short-term interactions between stock-index cash and futures markets (Chan et al. 2004).

Nevertheless, these REIT results are consistent with the findings of Tornell and Yuan (2012) for the currency markets and Quan (1992) for the crude oil markets. As discussed by Quan (1992) and Tornell and Yuan (2012), the unique investor structure might be the reason that there is short-term price discovery in the A-REIT cash market rather than in the A-REIT futures market. According to Horng and Wei (1999), US REITs do not have strong incentives to use derivatives for speculative purposes (i.e., to trade for profits). Importantly, the use of derivatives for speculative purposes might result in the loss of favourable tax status. In particular, numerous A-REITs have mandates specifying that derivative instruments are not to be traded for speculative purposes. Therefore, many A-REITs use 
Table 2. Estimation of the EC-VAR-BEKK-GARCH-X model

This table presents the estimation results of the model for the full sample period:

$$
\begin{aligned}
& \Delta c_{t}=\alpha_{c 0}+\alpha_{c 1} \Delta c_{t-1}+\alpha_{c 2} \Delta f_{t-1}+\alpha_{c 3} \Delta s c_{t}+\alpha_{c 4} \Delta g b_{t}+\alpha_{c 5} e c t_{t-1}+\varepsilon_{c t}, \\
& \Delta f_{t}=\alpha_{f 0}+\alpha_{f 1} \Delta c_{t-1}+\alpha_{f 2} \Delta f_{t-1}+\alpha_{f 3} \Delta s c_{t}+\alpha_{f 4} \Delta g b_{t}+\alpha_{f 5} e c t_{t-1}+\varepsilon_{f t}, \\
& h_{c c t}=c_{c c}^{2}+a_{c c}^{2} \varepsilon_{c t-1}^{2}+a_{f c}^{2} \varepsilon_{f t-1}^{2}+2 a_{c c} a_{f c} \varepsilon_{c t-1} \varepsilon_{f t-1}+b_{c c}^{2} h_{c c t-1}+b_{f c}^{2} h_{f f t-1}+2 b_{c c} b_{f c} h_{c f t-1}+k_{s c c}^{2} s_{t}^{2}+k_{e c c}^{2} e c t_{t-1}^{2}, \\
& h_{f f t}=c_{f f}^{2}+a_{f f}^{2} \varepsilon_{f t-1}^{2}+a_{c f}^{2} \varepsilon_{c t-1}^{2}+2 a_{f f} a_{c f} \varepsilon_{f t-1} \varepsilon_{c t-1}+b_{f f}^{2} h_{f f t-1}+b_{c f}^{2} h_{c c t-1}+2 b_{f f} b_{c f} h_{f c t-1}+k_{s f f}^{2} s_{t}^{2}+k_{e f f}^{2} e c t_{t-1}^{2} .
\end{aligned}
$$

\begin{tabular}{|c|c|c|c|c|c|c|c|}
\hline \multicolumn{4}{|c|}{ Cash market } & \multicolumn{4}{|c|}{ Futures market } \\
\hline \multicolumn{8}{|c|}{ Panel A: conditional mean } \\
\hline Var. & Coef. & Est. & t-value & Var. & Coef. & Est. & t-value \\
\hline Const. & $\alpha_{c 0}$ & 0.000 & -0.872 & Const. & $\alpha_{f 0}$ & 0.000 & -0.168 \\
\hline$\Delta c_{t-1}$ & $\alpha_{c 1}$ & 0.013 & 0.462 & $\Delta c_{t-1}$ & $\alpha_{f 1}$ & 0.184 & $2.393^{* *}$ \\
\hline$\Delta f_{t-1}$ & $\alpha_{c 2}$ & -0.006 & -0.260 & $\Delta f_{t-1}$ & $\alpha_{f 2}$ & -0.176 & $-2.195^{* *}$ \\
\hline$\Delta s c_{t}$ & $\alpha_{c 3}$ & 0.762 & $27.703^{* * *}$ & $\Delta s c_{t}$ & $\alpha_{f 3}$ & 0.714 & $17.355^{* * *}$ \\
\hline$\Delta g b_{t}$ & $\alpha_{c 4}$ & 0.006 & 0.119 & $\Delta g b_{t}$ & $\alpha_{f 4}$ & -0.012 & -0.166 \\
\hline$e c t_{t-1}$ & $\alpha_{c 5}$ & -0.007 & -0.652 & $e c t_{t-1}$ & $\alpha_{f 5}$ & -0.101 & $-3.745^{* * *}$ \\
\hline \multicolumn{8}{|c|}{ Panel B: conditional variance } \\
\hline Var. & Coef. & Est. & t-value & Var. & Coef. & Est. & t-value \\
\hline$\varepsilon_{c t-1}^{2}$ & $a_{c c}$ & 0.277 & $4.298^{* * *}$ & $\varepsilon_{f t-1}^{2}$ & $a_{f f}$ & 0.578 & $1.976^{* *}$ \\
\hline$\varepsilon_{f t-1}^{2}$ & $a_{f c}$ & -0.042 & -0.589 & $\varepsilon_{c t-1}^{2}$ & $a_{c f}$ & -0.129 & -0.411 \\
\hline$h_{c c t-1}$ & $b_{c c}$ & 0.865 & $10.773^{* * *}$ & $h_{f f t-1}$ & $b_{f f}$ & 0.427 & $2.968^{* * *}$ \\
\hline$h_{f f t-1}$ & $b_{f c}$ & 0.091 & 1.201 & $h_{c c t-1}$ & $b_{c f}$ & 0.455 & $2.886^{* * *}$ \\
\hline$s_{t}^{2}$ & $k_{s c c}$ & -0.002 & $-3.376^{* * *}$ & $s_{t}^{2}$ & $k_{s f f}$ & -0.002 & $-2.525^{* *}$ \\
\hline$e c t_{t-1}^{2}$ & $k_{e c c}$ & -0.020 & 0.214 & $e c t_{t-1}^{2}$ & $k_{\text {eff }}$ & 0.106 & 0.170 \\
\hline
\end{tabular}

Notes: 1. Newey-West adjusted t-values are in parentheses. 2. Var. stands for variance, and Coef. stands for coefficient. Est. is estimate, and Cont. is constant. $3 .{ }^{*},{ }^{* *}$ and $* * *$ denote statistical significance at the $10 \%, 5 \%$ and $1 \%$ levels, respectively.

derivatives for hedging rather than for speculative purposes. Comparable results in Australia are also documented by Lee (2010). Therefore, the A-REIT cash market should play a leading role because hedgers use cash prices to make decisions regarding futures prices; thus, futures prices are formed after the cash price is established in the markets.

Regarding the own lagged terms, the coefficient of the lagged A-REIT cash index changes in the cash equation $\left(\alpha_{c 1}\right)$ has a positive sign but is not statistically significant, which implies that the previous day's A-REIT returns contain no information about the current day's A-REIT returns. The corresponding coefficient in the futures equation $\left(\alpha_{f 2}\right)$ is significant at the $5 \%$ level and has a negative sign. Thus, by contrast to the A-REIT cash market, the previous day's A-REIT futures returns contain information about the current day's A-REIT futures returns. Specifically, daily changes in the A-REIT futures price exhibit mean-reversion, which can be attributed to the fact that A-REIT futures trading is primarily motivated by hedging. Hedging trades typically generate negatively autocorrelated returns because the trades do not reflect new information and the expected payoff from the asset remains identical. Thus, the asset price must decrease during this period to attract traders on the other side of the transaction (Ciner 2006). The 
price subsequently returns to its original starting position in the next period because the fundamental value remains the same (Ciner 2006).

In addition, the coefficients on the stock returns in the cash $\left(\alpha_{c 3}\right)$ and futures equations $\left(\alpha_{f 3}\right)$ are positive and significant at the $1 \%$ level. The result of $\alpha_{c 3}$ in the cash equation is consistent with the findings of Chiang et al. (2005) and Cotter and Stevenson (2006) because A-REITs are traded in the stock market. The sign of $\alpha_{f 3}$ for the futures market is consistent with the finding that is discussed above. Because REIT futures are constructed based on REITs whose returns are positively linked with stock returns, it is not surprising to find that stock returns have a significant and positive influence on REIT futures returns.

The stock return coefficients also indicate that a 1\% increase in the All Ordinaries index returns generates increases of $0.762 \%$ and $0.714 \%$ in the S\&P/ASX 200-A-REIT index returns and index futures returns, respectively. Because both types of returns have identical constituent REITs, it is not surprising that the REIT cash index and index futures returns react in a statistically similar manner, particularly with respect to magnitude. The magnitudes also reflect the fact that the A-REIT cash market is an important sector in the Australian stock market. More importantly, these results indicate that A-REIT cash and futures returns are strongly influenced by stock returns. Therefore, it is essential that stock returns are included in the modelling of A-REIT cash and futures returns.

The bond return coefficients are also positive. However, the coefficient in the cash equation $\left(\alpha_{c 4}\right)$ indicates that there is no significant connection between A-REIT daily returns and bond returns. The corresponding coefficient in the futures equation $\left(\alpha_{f 4}\right)$ is also not significant. These findings are thus consistent with previous studies on equity REIT $^{6}$ (Yang et al. 2012) and A-REIT futures returns (Lee 2009).

As predicted by the arbitrage/hedging argument, the error-correction term in the futures market equation has a negative coefficient $\left(\alpha_{f 5}\right)$. Consistent with the momentum effect argument, the corresponding coefficient $\left(\alpha_{c 5}\right)$ in the cash market equation is positive. As expected, $\alpha_{f 5}$ has a larger absolute value than $\alpha_{c 5}$, which is required to restore the long-term equilibrium between the cash and futures markets and implies long-term price discovery in the cash market. Moreover, the errorcorrection term in the cash market equation is not

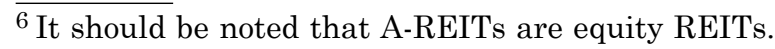

statistically significant, whereas the corresponding term in the futures market equation is significant at the $1 \%$ level, which indicates that the futures price adjusts to error-correct the temporary mispricing that occurs during events of disequilibria but the cash market price does not. These results thus imply long-term price discovery in the cash market and again contradict the general understanding about the long-term relationship between stock-index cash and futures markets (Chan et al. 2004).

Panel B presents the empirical results of the conditional variance equations. Specifically, the past shock coefficients (the ARCH effects) measure the impacts of "recent news", and the past variance coefficients (the GARCH effects) link the influence of "old news" to price changes. In the cash market equation, the own past shock coefficient $\left(a_{c c}\right)$ is statistically significant at the $1 \%$ level, but the cross-market shock spillover coefficient $\left(a_{f c}\right)$ is not significant. These coefficients suggest that the impact of "recent news" on A-REIT volatility comes from the cash market and not from the futures market. Similarly, the own past variance coefficient $\left(b_{c c}\right)$ in the cash market equation is statistically significant, and the cross-market variance spillover coefficient $\left(b_{f c}\right)$ is not significant, which indicate that the impacts of "old news" on A-REIT price changes also come from the cash market and not from the futures market. Importantly, the cross-market coefficients in the cash market clearly show no short-term volatility spillovers from the A-REIT futures market. These results are consistent with the findings of Lee et al. (2014) in European real estate securities markets.

In the futures market equation, the own past shock coefficient $\left(a_{f f}\right)$ is significant at the $5 \%$ level, and the cross-market shock spillover coefficient $\left(a_{c f}\right)$ is not statistically significant. These coefficients suggest that the impact of "recent news" on A-REIT futures volatility comes from the futures market and not from the cash market. The own past variance coefficient $\left(b_{f f}\right)$ in the futures market equation and the cross-market variance spillover coefficient $\left(b_{c f}\right)$ are both statistically significant. These coefficients indicate that the impact of "old news" on A-REIT futures price changes comes from both the futures market itself and the cash market. Clearly, the cross-market coefficients indicate short-term volatility spillovers from the AREIT cash market to the A-REIT futures market, but not vice versa.

With respect to the influence of broad market changes, the stock market shock coefficients in the 
cash equation $\left(k_{s c c}\right)$ and the corresponding coefficient in the futures equation $\left(k_{s f f}\right)$ are statistically significant. The significant coefficients indicate that contemporaneous broad market changes clearly influence the conditional variance of the REIT cash and futures markets. The significant coefficient in the cash equation is consistent with Cotter and Stevenson (2007). These findings in the futures market are consistent with the univariate GARCH study of Lee (2009).

With respect to long-term volatility spillovers, neither the coefficients of the squared error-correction terms $\left(k_{e c c}\right)$ in the cash market equation nor the corresponding coefficient $\left(k_{\text {eff }}\right)$ are statistically significant. These coefficients do not indicate that the price deviations from their long-term equilibrium affect conditional variances in the A-REIT cash and futures markets. Thus, the results do not support the long-term volatility spillover hypothesis. The likely reason is that the full sample period results are driven by the GFC sub-period results, which show that the A-REIT futures market is more informationally efficient during the crisis period.

Table 3 summarises the results discussed above. Although the results of the conditional variance equation reveal only short-run links between the A-REIT cash and futures markets, the results of the mean equation indicate that the A-REIT cash market serves as the primary market and that price discovery occurs in this market both in the short and long runs. These results indicate that the first (return) and second moments (volatility) may contain different information sets; these results also highlight the importance for investors to analyse both return and volatility patterns (Kallberg et al. 2002; Lee 2009). More importantly, by contrast to the previous literature regarding stock-index futures markets, this study shows that the A-REIT futures market does not fully perform the expected price discovery function. This result might be attributed to the investor structure of the A-REIT futures market, which may influence both the price discovery and volatility transmission processes.

Table 3. Summary results table for the full sample period

\begin{tabular}{lll}
\hline Hypothesis & Support & Leading market \\
\hline Short-term Prediction & Yes & Cash \\
Long-term Prediction & Yes & Cash \\
$\begin{array}{l}\text { Short-term Volatility } \\
\text { Spillover }\end{array}$ & Yes & Cash \\
$\begin{array}{l}\text { Long-term Volatility } \\
\text { Spillover }\end{array}$ & No & Neither \\
\hline
\end{tabular}

\subsection{GFC, price discovery, and volatility transmission}

This section examines the effects of the GFC on price discovery and volatility transmission in AREIT futures. The full sample period was divided into pre-GFC, GFC, and post-GFC periods, and the results are presented in Tables 4, 5, and 6 . The evidence regarding price discovery and volatility spillovers differs remarkably across the three samples; moreover, several detailed findings are of particular importance.

For the pre-GFC period, the mean equation results are broadly similar to those for the full sample period. In particular, there is short-term price discovery in the cash market but not in the futures market. Long-term price discovery in the A-REIT cash market is also documented, whereas there is no comparable evidence available for the futures market. However, the conditional variance equation results for the pre-GFC period are somewhat different from those for the full sample period. In particular, the results still suggest that unilateral volatility spillovers occur from the A-REIT cash market into the A-REIT futures market over the short run. Another important observation is that the error-correction term in the A-REIT futures market is statistically significant, which indicates that trading activities may affect the volatility of the A-REIT futures market in response to deviations from equilibrium. This significant link supports the conjecture from the previous section regarding the long-term volatility spillover hypothesis.

During the GFC, the price discovery and volatility spillover patterns differ from those same patterns preceding the GFC. With respect to the short-term prediction hypothesis, the results show a bilateral lead-lag relationship during this period. In other words, not only do A-REIT cash returns have considerable predictive power for A-REIT futures returns but A-REIT futures returns are useful for predicting A-REIT cash returns. This finding indicates the presence of a two-way flow of information exchange between the A-REIT cash and futures markets during the GFC period. This finding reveals an improvement in informational efficiency in the A-REIT futures market because the A-REIT futures trading volume had increased significantly during the GFC. Because A-REIT futures are mainly used for hedging purposes, it is reasonable that there is a higher hedging demand for futures during the volatile period. Increased demand and higher premiums from hedgers during 
Table 4. Estimation of the EC-VAR-BEKK-GARCH-X model pre-GFC

This table presents the estimation results of the model below for the pre-GFC period:

$$
\begin{aligned}
& \Delta c_{t}=\alpha_{c 0}+\alpha_{c 1} \Delta c_{t-1}+\alpha_{c 2} \Delta f_{t-1}+\alpha_{c 3} \Delta s c_{t}+\alpha_{c 4} \Delta g b_{t}+\alpha_{c 5} e c t_{t-1}+\varepsilon_{c t}, \\
& \Delta f_{t}=\alpha_{f 0}+\alpha_{f 1} \Delta c_{t-1}+\alpha_{f 2} \Delta f_{t-1}+\alpha_{f 3} \Delta s c_{t}+\alpha_{f 4} \Delta g b_{t}+\alpha_{f 5} e c t_{t-1}+\varepsilon_{f t}, \\
& h_{c c t}=c_{c c}^{2}+a_{c c}^{2} \varepsilon_{c t-1}^{2}+a_{f c}^{2} \varepsilon_{f t-1}^{2}+2 a_{c c} a_{f c} \varepsilon_{c t-1} \varepsilon_{f t-1}+b_{c c}^{2} h_{c c t-1}+b_{f c}^{2} h_{f f t-1}+2 b_{c c} b_{f c} h_{c f t-1}+k_{s c c}^{2} s_{t}^{2}+k_{e c c}^{2} e c t_{t-1}^{2}, \\
& h_{f f t}=c_{f f}^{2}+a_{f f}^{2} \varepsilon_{f t-1}^{2}+a_{c f}^{2} \varepsilon_{c t-1}^{2}+2 a_{f f} a_{c f} \varepsilon_{f t-1} \varepsilon_{c t-1}+b_{f f}^{2} h_{f f t-1}+b_{c f}^{2} h_{c c t-1}+2 b_{f f} b_{c f} h_{f c t-1}+k_{s f f}^{2} s_{t}^{2}+k_{e f f}^{2} e c t_{t-1}^{2} .
\end{aligned}
$$

\begin{tabular}{|c|c|c|c|c|c|c|c|}
\hline \multicolumn{4}{|c|}{ Cash market } & \multicolumn{4}{|c|}{ Futures market } \\
\hline \multicolumn{8}{|c|}{ Panel A: conditional mean } \\
\hline Var. & Coef. & Est. & t-value & Var. & Coef. & Est. & t-value \\
\hline Const. & $\alpha_{c 0}$ & 0.000 & 0.485 & Const. & $\alpha_{f 0}$ & 0.000 & -0.451 \\
\hline$\Delta c_{t-1}$ & $\alpha_{c 1}$ & -0.078 & -0.973 & $\Delta c_{t-1}$ & $\alpha_{f 1}$ & 0.354 & $3.599^{* * *}$ \\
\hline$\Delta f_{t-1}$ & $\alpha_{c 2}$ & 0.052 & 0.652 & $\Delta f_{t-1}$ & $\alpha_{f 2}$ & -0.366 & $-4.126^{* * *}$ \\
\hline$\Delta s c_{t}$ & $\alpha_{c 3}$ & 0.726 & $12.461^{* * *}$ & $\Delta s c_{t}$ & $\alpha_{f 3}$ & 0.684 & $11.774^{* * *}$ \\
\hline$\Delta g b_{t}$ & $\alpha_{c 4}$ & 0.000 & 0.000 & $\Delta g b_{t}$ & $\alpha_{f 4}$ & -0.046 & -0.419 \\
\hline$e c t_{t-1}$ & $\alpha_{c 5}$ & -0.044 & -1.196 & $e c t_{t-1}$ & $\alpha_{f 5}$ & -0.079 & $-1.896^{*}$ \\
\hline \multicolumn{8}{|c|}{ Panel B: conditional variance } \\
\hline Var. & Coef. & Est. & t-value & Var. & Coef. & Est. & t-value \\
\hline$\varepsilon_{c t-1}^{2}$ & $a_{c c}$ & 0.218 & $2.058^{* *}$ & $\varepsilon_{f t-1}^{2}$ & $a_{f f}$ & 0.503 & $2.954^{* * *}$ \\
\hline$\varepsilon_{f t-1}^{2}$ & $a_{f c}$ & -0.132 & -1.424 & $\varepsilon_{c t-1}^{2}$ & $a_{c f}$ & -0.677 & $-3.004^{* * *}$ \\
\hline$h_{c c t-1}$ & $b_{c c}$ & 0.677 & 1.076 & $h_{f f t-1}$ & $b_{f f}$ & 0.005 & 0.019 \\
\hline$h_{f f t-1}$ & $b_{f_{c}}$ & 0.584 & 1.028 & $h_{c c t-1}$ & $b_{c f}$ & 0.012 & 0.034 \\
\hline$s_{t}^{2}$ & $k_{s c c}$ & 0.000 & 1.241 & $s_{t}^{2}$ & $k_{s f f}$ & 0.001 & 1.193 \\
\hline$e c t_{t-1}^{2}$ & $k_{e c c}$ & 0.026 & 0.696 & $e c t_{t-1}^{2}$ & $k_{e f f}$ & -0.339 & $-4.405^{* * *}$ \\
\hline
\end{tabular}

Notes: 1. Newey-West adjusted t-values are in parentheses. 2. Var. stands for variance, and Coef. stands for coefficient. Est. is estimate, and Cont. is constant. 3. ${ }^{*}, * *$ and $* * *$ denote statistical significance at the $10 \%, 5 \%$ and $1 \%$ levels, respectively.

the GFC might have attracted more informed speculators into the A-REIT futures market (Xiang et al. 2013). Increased speculative trading that is a consequence of the asymmetric information held by certain informed traders thus improves the informational efficiency of the A-REIT futures market (Ciner 2006).

Notably, the coefficient of the own lagged return in the A-REIT futures market equation becomes smaller in absolute value, which indicates that the previous day's A-REIT futures returns contain less information about the current day's
A-REIT futures returns. The smaller coefficient therefore also lends support for informational efficiency improvement in the A-REIT futures market. With regard to long-term volatility spillovers, by contrast to those in the pre-GFC period, neither the cash market nor the futures market led the other in terms of information flow during the GFC. Therefore, as in the full sample period, the longterm volatility spillovers hypothesis is not supported during the GFC period, which also reflects the improved price discovery performance of the A-REIT futures market. As a result, the futures 
Table 5. Estimation of the EC-VAR-BEKK-GARCH-X model during the GFC

This table presents the estimation results of the model below during the GFC period:

$$
\begin{aligned}
& \Delta c_{t}=\alpha_{c 0}+\alpha_{c 1} \Delta c_{t-1}+\alpha_{c 2} \Delta f_{t-1}+\alpha_{c 3} \Delta s c_{t}+\alpha_{c 4} \Delta g b_{t}+\alpha_{c 5} e c t_{t-1}+\varepsilon_{c t}, \\
& \Delta f_{t}=\alpha_{f 0}+\alpha_{f 1} \Delta c_{t-1}+\alpha_{f 2} \Delta f_{t-1}+\alpha_{f 3} \Delta s c_{t}+\alpha_{f 4} \Delta g b_{t}+\alpha_{f 5} e c t_{t-1}+\varepsilon_{f t}, \\
& h_{c c t}=c_{c c}^{2}+a_{c c}^{2} \varepsilon_{c t-1}^{2}+a_{f c}^{2} \varepsilon_{f t-1}^{2}+2 a_{c c} a_{f c} \varepsilon_{c t-1} \varepsilon_{f t-1}+b_{c c}^{2} h_{c c t-1}+b_{f c}^{2} h_{f f t-1}+2 b_{c c} b_{f c} h_{c f t-1}+k_{s c c}^{2} s_{t}^{2}+k_{e c c}^{2} e c t_{t-1}^{2}, \\
& h_{f f t}=c_{f f}^{2}+a_{f f}^{2} \varepsilon_{f t-1}^{2}+a_{c f}^{2} \varepsilon_{c t-1}^{2}+2 a_{f f} a_{c f} \varepsilon_{f t-1} \varepsilon_{c t-1}+b_{f f}^{2} h_{f f t-1}+b_{c f}^{2} h_{c c t-1}+2 b_{f f} b_{c f} h_{f c t-1}+k_{s f f}^{2} s_{t}^{2}+k_{e f f}^{2} e c t_{t-1}^{2} .
\end{aligned}
$$

\begin{tabular}{|c|c|c|c|c|c|c|c|}
\hline \multicolumn{4}{|c|}{ Cash market } & \multicolumn{4}{|c|}{ Futures market } \\
\hline \multicolumn{8}{|c|}{ Panel A: Conditional mean } \\
\hline Var. & Coef. & Est. & t-value & Var. & Coef. & Est. & t-value \\
\hline Const. & $\alpha_{c 0}$ & -0.002 & $-2.905^{* * *}$ & Const. & $\alpha_{f 0}$ & -0.002 & $-2.406^{* *}$ \\
\hline$\Delta c_{t-1}$ & $\alpha_{c 1}$ & 0.127 & $3.507^{* * *}$ & $\Delta c_{t-1}$ & $\alpha_{f 1}$ & 0.104 & $2.085^{* *}$ \\
\hline$\Delta f_{t-1}$ & $\alpha_{c 2}$ & -0.081 & $-3.035^{* * *}$ & $\Delta f_{t-1}$ & $\alpha_{f 2}$ & -0.069 & $-1.759^{*}$ \\
\hline$\Delta s c_{t}$ & $\alpha_{c 3}$ & 1.037 & $12.064^{* * *}$ & $\Delta s c_{t}$ & $\alpha_{f 3}$ & 0.987 & $10.212^{* * *}$ \\
\hline$\Delta g b_{t}$ & $\alpha_{c 4}$ & 0.127 & 0.671 & $\Delta g b_{t}$ & $\alpha_{f 4}$ & -0.009 & -0.042 \\
\hline$e c t_{t-1}$ & $\alpha_{c 5}$ & -0.003 & -0.164 & $e c t_{t-1}$ & $\alpha_{f 5}$ & -0.068 & $-1.977^{* *}$ \\
\hline \multicolumn{8}{|c|}{ Panel B: Conditional Variance } \\
\hline Var. & Coef. & Est. & t-value & Var. & Coef. & Est. & t-value \\
\hline$\varepsilon_{c t-1}^{2}$ & $a_{c c}$ & 0.361 & $4.118^{* * *}$ & $\varepsilon_{f t-1}^{2}$ & $a_{f f}$ & 0.208 & 0.932 \\
\hline$\varepsilon_{f t-1}^{2}$ & $a_{f c}$ & 0.006 & 0.124 & $\varepsilon_{c t-1}^{2}$ & $a_{c f}$ & 0.341 & $2.066^{* *}$ \\
\hline$h_{c c t-1}$ & $b_{c c}$ & 0.797 & $5.545^{* * *}$ & $h_{f f t-1}$ & $b_{f f}$ & 0.335 & 0.705 \\
\hline$h_{f f t-1}$ & $b_{f c}$ & 0.098 & 0.753 & $h_{c c t-1}$ & $b_{c f}$ & 0.408 & 0.864 \\
\hline$s_{t}^{2}$ & $k_{s c c}$ & -0.005 & $-3.202^{* * *}$ & $s_{t}^{2}$ & $k_{s f f}$ & 0.003 & $2.871^{* * *}$ \\
\hline$e c t_{t-1}^{2}$ & $k_{e c c}$ & 0.009 & 0.157 & $e c t_{t-1}^{2}$ & $k_{e f f}$ & -0.254 & -1.493 \\
\hline
\end{tabular}

Notes: 1. Newey-West adjusted t-values are in parentheses. 2. Var. stands for variance, and Coef. stands for coefficient. Est. is estimate, and Cont. is constant. 3. * ${ }^{* *}$ and $* * *$ denote statistical significance at the $10 \%, 5 \%$ and $1 \%$ levels, respectively.

market no longer follows the cash market during the GFC in terms of price prediction and volatility transmission. These results are broadly consistent with the findings of Xiang et al. (2013), who report similar results for the CDS market.

For the post-GFC period, the overall mean equation results provide information that is different from the results provided from the period during the GFC but similar to those findings documented from before the GFC. Specifically, there is evidence of long-term price discovery in the A-REIT cash market instead of in the futures market.
Nevertheless, neither of the cross-market lagged returns is significant, and therefore, they do not support the short-term prediction hypothesis.

Another important observation is that the insignificant coefficient of lagged futures return suggests that the A-REIT futures market has remained informationally efficient since the GFC period. These findings are also consistent with the fact that the A-REIT cash (futures) market has become less volatile (less heavily traded) following the GFC, although it remains more volatile (more heavily traded) than during the pre-GFC period. 
Table 6. Estimation of the EC-VAR-BEKK-GARCH-X model post-GFC

This table presents the estimation results of the model below for the post-GFC period:

$$
\begin{aligned}
& \Delta c_{t}=\alpha_{c 0}+\alpha_{c 1} \Delta c_{t-1}+\alpha_{c 2} \Delta f_{t-1}+\alpha_{c 3} \Delta s c_{t}+\alpha_{c 4} \Delta g b_{t}+\alpha_{c 5} e c t_{t-1}+\varepsilon_{c t}, \\
& \Delta f_{t}=\alpha_{f 0}+\alpha_{f 1} \Delta c_{t-1}+\alpha_{f 2} \Delta f_{t-1}+\alpha_{f 3} \Delta s c_{t}+\alpha_{f 4} \Delta g b_{t}+\alpha_{f 5} e c t_{t-1}+\varepsilon_{f t}, \\
& h_{c c t}=c_{c c}^{2}+a_{c c}^{2} \varepsilon_{c t-1}^{2}+a_{f c}^{2} \varepsilon_{f t-1}^{2}+2 a_{c c} a_{f c} \varepsilon_{c t-1} \varepsilon_{f t-1}+b_{c c}^{2} h_{c c t-1}+b_{f c}^{2} h_{f f t-1}+2 b_{c c} b_{f c} h_{c f t-1}+k_{s c c}^{2} s_{t}^{2}+k_{e c c}^{2} e c t_{t-1}^{2}, \\
& h_{f f t}=c_{f f}^{2}+a_{f f}^{2} \varepsilon_{f t-1}^{2}+a_{c f}^{2} \varepsilon_{c t-1}^{2}+2 a_{f f} a_{c f} \varepsilon_{f t-1} \varepsilon_{c t-1}+b_{f f}^{2} h_{f f t-1}+b_{c f}^{2} h_{c c t-1}+2 b_{f f} b_{c f} h_{f c t-1}+k_{s f f}^{2} s_{t}^{2}+k_{e f f}^{2} e c t_{t-1}^{2} .
\end{aligned}
$$

\begin{tabular}{|c|c|c|c|c|c|c|c|}
\hline \multicolumn{4}{|c|}{ Cash market } & \multicolumn{4}{|c|}{ Futures market } \\
\hline \multicolumn{8}{|c|}{ Panel A: conditional mean } \\
\hline Var. & Coef. & Est. & t-value & Var. & Coef. & Est. & t-value \\
\hline Const. & $\alpha_{c 0}$ & 0.001 & 1.042 & Const. & $\alpha_{f 0}$ & 0.001 & 1.154 \\
\hline$\Delta c_{t-1}$ & $\alpha_{c 1}$ & -0.102 & -1.467 & $\Delta c_{t-1}$ & $\alpha_{f 1}$ & -0.047 & -0.558 \\
\hline$\Delta f_{t-1}$ & $\alpha_{c 2}$ & 0.048 & 0.982 & $\Delta f_{t-1}$ & $\alpha_{f 2}$ & -0.016 & -0.241 \\
\hline$\Delta s c_{t}$ & $\alpha_{c 3}$ & 0.778 & $9.733^{* * *}$ & $\Delta s c_{t}$ & $\alpha_{f 3}$ & 0.742 & $8.899^{* * *}$ \\
\hline$\Delta g b_{t}$ & $\alpha_{c 4}$ & 0.114 & 0.768 & $\Delta g b_{t}$ & $\alpha_{f 4}$ & 0.223 & 1.569 \\
\hline$e c t_{t-1}$ & $\alpha_{c 5}$ & -0.010 & -0.362 & $e c t_{t-1}$ & $\alpha_{f 5}$ & -0.079 & $-2.780^{* * *}$ \\
\hline \multicolumn{8}{|c|}{ Panel B: conditional variance } \\
\hline Var. & Coef. & Est. & t-value & Var. & Coef. & Est. & $t$-value \\
\hline$\varepsilon_{c t-1}^{2}$ & $a_{c c}$ & -0.345 & $-1.962^{* *}$ & $\varepsilon_{f t-1}^{2}$ & $a_{f f}$ & 0.083 & 0.426 \\
\hline$\varepsilon_{f t-1}^{2}$ & $a_{f c}$ & 0.160 & 0.934 & $\varepsilon_{c t-1}^{2}$ & $a_{c f}$ & -0.659 & $-2.054^{* *}$ \\
\hline$h_{c c t-1}$ & $b_{c c}$ & -0.612 & $-3.706^{* * *}$ & $h_{f f t-1}$ & $b_{f f}$ & 0.646 & $2.427^{* *}$ \\
\hline$h_{f f t-1}$ & $b_{f c}$ & 0.102 & 0.374 & $h_{c c t-1}$ & $b_{c f}$ & -0.818 & $-1.989^{* *}$ \\
\hline$s_{t}^{2}$ & $k_{s c c}$ & 0.001 & $4.354^{* * *}$ & $s_{t}^{2}$ & $k_{s f f}$ & 0.001 & 0.930 \\
\hline$e c t_{t-1}^{2}$ & $k_{e c c}$ & 0.004 & 0.367 & $e c t_{t-1}^{2}$ & $k_{e f f}$ & 0.154 & $4.463^{* * *}$ \\
\hline
\end{tabular}

Notes: 1. Newey-West adjusted t-values are in parentheses. 2. Var. stands for variance, and Coef. stands for coefficient. Est. is estimate, and Cont. is constant. $3 .{ }^{*},{ }^{* *}$ and $* * *$ denote statistical significance at the $10 \%, 5 \%$ and $1 \%$ levels, respectively.

Thus, the demand for risk sharing in the REIT futures market remains strong, and the market remains attractive to informed speculators (Xiang et al. 2013).

The overall conditional variance equation results for the post-GFC period also convey information that is different from that conveyed during the GFC but similar to the documented findings from before the GFC period. Specifically, these coefficients in the variance equations imply unilateral volatility spillovers from the A-REIT cash markets to the futures markets. Nevertheless, the cross- market shock and variance spillover coefficients in the futures market equation indicate that the A-REIT futures market is less responsive to the cash market during the post-GFC period than it was during the pre-GFC period. As it has become statistically significant, the error-correction term in the REIT futures market equation also reveals a similar message.

These findings are consistent with the fact that the A-REIT cash (futures) market is more volatile (more heavily traded) during the post-GFC period than during the pre-GFC period. These findings 
are also broadly consistent with the mean equation results regarding the implication that the market remains more attractive to informed speculators in the post-GFC period than during the pre-GFC period.

The key findings are summarised in Table 7 . Overall, the A-REIT cash market led the A-REIT futures market in the price discovery and volatility transmission processes before the GFC. During the GFC period, the two markets interacted bilaterally in terms of short-term price discovery, and the futures market stopped following the cash market with respect to long-term volatility spillovers. Furthermore, after the GFC, the futures market again began following the cash market regarding long-term price discovery and volatility spillovers. However, A-REIT cash returns do not have predictive power for A-REIT futures returns during the post-GFC period.

Table 7. Summary results table for sub-periods

\begin{tabular}{|c|c|c|}
\hline Hypothesis & Support & Leading market \\
\hline \multicolumn{3}{|l|}{ Panel A: Pre-GFC period } \\
\hline Short-term Prediction & Yes & Cash \\
\hline Long-term Prediction & Yes & Cash \\
\hline $\begin{array}{l}\text { Short-term Volatility } \\
\text { Spillover }\end{array}$ & Yes & Cash \\
\hline $\begin{array}{l}\text { Long-term Volatility } \\
\text { Spillover }\end{array}$ & Yes & Cash \\
\hline \multicolumn{3}{|l|}{ Panel B: GFC period } \\
\hline Short-term Prediction & Yes & Both \\
\hline Long-term Prediction & Yes & Cash \\
\hline $\begin{array}{l}\text { Short-term Volatility } \\
\text { Spillover }\end{array}$ & Yes & Cash \\
\hline $\begin{array}{l}\text { Long-term Volatility } \\
\text { Spillover }\end{array}$ & No & Neither \\
\hline \multicolumn{3}{|c|}{ Panel C: Post-GFC period } \\
\hline Short-term Prediction & No & Neither \\
\hline Long-term Prediction & Yes & Cash \\
\hline $\begin{array}{l}\text { Short-term Volatility } \\
\text { Spillover }\end{array}$ & Yes & Cash \\
\hline $\begin{array}{l}\text { Long-term Volatility } \\
\text { Spillover }\end{array}$ & Yes & Cash \\
\hline
\end{tabular}

\section{CONCLUSIONS}

This study examines price discovery and volatility transmission between the A-REIT futures market and the cash market, which has not yet been addressed in the literature. This study provides a number of important insights. First, the cash AREIT market clearly dominates the futures market with respect to the information transmission processes. These results stand in sharp contrast to extensive stock index studies in which futures markets lead cash markets. Second, the sub-period analyses demonstrate that structural changes did occur in the A-REIT futures market during and after the GFC. Specifically, the price discovery function for A-REIT futures has shown improvement since the GFC, which can be attributed to dramatic increases in the activity of A-REIT futures since the GFC. It also implies that, during and after the GFC, informed speculators likely entered the A-REIT futures market and improved its price discovery function. The findings support the recent literature that indicates that the role of the futures markets in the price formation process is related to investor structure.

These findings have important practical implications for investors. First, investors should be aware of the link between the investor structure of a futures market and the role of the futures market. Specifically, the role of A-REIT futures in price discovery and volatility spillovers is timevarying, which may be attributed to the investor structure of A-REIT futures in which the market is much smaller than the underlying cash market. Second, A-REIT futures contain some information regarding the A-REIT cash market during periods of extreme volatility. In particular, during the GFC, the previous day's futures market returns impacted the current day's cash market returns. Therefore, property analysts and property investors, including direct property investors, should include information from A-REIT futures in their investment analyses and strategies during periods of volatility.

\section{ACKNOWLEDGEMENTS}

The authors would like to thank two anonymous referees for their comments and suggestions. Grant support from Taiwan's Ministry of Science and Technology (NSC 100-2410-H-259-026-) is gratefully acknowledged.

\section{REFERENCES}

Allen, M. T.; Madura, J.; Springer, T. M. 2000. REIT characteristics and the sensitivity of REIT returns, Journal of Real Estate Finance and Economics 21(2): 141-152. http://dx.doi.org/10.1023/A:1007839809578

Anderson, R.; Clayton, J.; Mackinnon, G.; Sharma, R. 2005. REIT returns and pricing: the small cap value stock factor, Journal of Property Research 22(4): 267286. http://dx.doi.org/10.1080/09599910600558454 
Australian Securities Exchange. 2013. ASX funds (listed managed investments and ETPS) monthly update: December 2012. Sydney: Australian Securities Exchange.

Barkham, R.; Geltner, D. 1995. Price discovery in American and British property markets, Real Estate Economics 23(1): 21-44. http://dx.doi.org/10.1111/1540-6229.00656

Bohl, M. T.; Salm, C. A.; Schuppli, M. 2011. Price discovery and investor structure in stock index futures, Journal of Futures Markets 31(3): 282-306. http://dx.doi.org/10.1002/fut.20469

Boudry, W. I.; Coulson, N. E.; Kallberg, J. G.; Liu, C. H. 2012. On the hybrid nature of REITs, Journal of Real Estate Finance and Economics 44(1-2): 230-249. http://dx.doi.org/10.1007/s11146-011-9339-7

Cabrera, J.; Wang, T.; Yang, J. 2009. Do futures lead price discovery in electronic foreign exchange markets?, Journal of Futures Markets 29(2): 137-156. http://dx.doi.org/10.1002/fut.20352

Chan, K.; Chan, K. C.; Karolyi, G. A. 1991. Intraday volatility in the stock index and stock index futures markets, Review of Financial Studies 4(4): 657-684. http://dx.doi.org/10.1093/rfs/4.4.657

Chan, S.-J.; Lin, C.-C.; Hsu, H. 2004. Do different futures contracts in one stock exchange have the same price discovery capability? Empirical study of Taiwan futures exchange, Journal of Financial Management and Analysis 17(1): 34-44.

Chiang, K. C.; Kozhevnikov, K.; Lee, M.-L.; Wisen, C. H. 2006. REIT mimicking portfolio analysis, International Real Estate Review 9(1): 95-111.

Chiang, K. C. H.; Lee, M. L.; Wisen, C. H. 2005. On the time-series properties of real estate investment trust betas, Real Estate Economics 33(2): 381-396. http://dx.doi.org/10.1111/j.1540-6229.2005.00123.x

Chng, M.; Wang, P. 2014. Rating downgrades and the price impact of CDS spread on stock return, Review of Futures Markets 21(3): 283-323.

Ciner, C. 2006. Hedging or speculation in derivative markets: the case of energy futures contracts, $A p$ plied Financial Economics Letters 2(3): 189-192. http://dx.doi.org/10.1080/17446540500461729

Clayton, J.; Mackinnon, G. 2003. The relative importance of stock, bond and real estate factors in explaining REIT returns, Journal of Real Estate Finance and Economics 27(1): 39-60. http://dx.doi.org/10.1023/A:1023607412927

Cotter, J.; Stevenson, S. 2006. Multivariate modeling of daily REIT volatility, Journal of Real Estate Finance and Economics 32(3): 305-325.

http://dx.doi.org/10.1007/s11146-006-6804-9

Cotter, J.; Stevenson, S. 2007. Uncovering volatility dynamics in daily REIT returns, Journal of Real Estate Portfolio Management 13(2): 119-128.

Goodchild, R. 2008. REITs - a global phenomenon, Journal of Property Investment and Finance 26(3). http://dx.doi.org/10.1108/jpif.2008.11226caa.001

Geltner, D.; MacGregor, B. D.; Schwann, G. M. 2003. Appraisal smoothing and price discovery in real estate markets, Urban Studies 40(5-6): 1047-1064. http://dx.doi.org/10.1080/0042098032000074317
Gyourko, J.; Keim, D. B. 1992. What does the stock market tell us about real estate returns?, AREUEA Journal 20(3): 457-485. http://dx.doi.org/10.1111/1540-6229.00591

Horng, Y. S.; Wei, P. 1999. An empirical study of derivatives use in the REIT industry, Real Estate Economics 27(3): 561-586. http://dx.doi.org/10.1111/1540-6229.00784

Kallberg, J. G.; Liu, C. H.; Pasquariello, P. 2002. Regime shifts in Asian equity and real estate markets, Real Estate Economics 30(2): 263-291. http://dx.doi.org/10.1111/1540-6229.00040

Koutmos, G.; Tucker, M. 1996. Temporal relationships and dynamic interactions between spot and futures stock markets, Journal of Futures Markets 16: 55-69. http://dx.doi.org/10.1002/(SICI)10969934(199602)16:1<55::AID-FUT3>3.0.CO;2-G

Lee, C. L. 2009. Volatility transmission in Australian REIT futures, Journal of Real Estate Portfolio Management 15(3): 221-238.

Lee, C. L. 2010. Use of derivatives by Australian property funds, Pacific Rim Property Research Journal 16(2): 151-170.

http://dx.doi.org/10.1080/14445921.2010.11104299

Lee, C. L.; Lee, M. L. 2012. Hedging effectiveness of REIT futures, Journal of Property Investment \& Finance 30(3): 257-281. http://dx.doi.org/10.1108/14635781211223824

Lee, C. L.; Stevenson, S.; Lee, M.-L. 2014. Futures trading, spot price volatility and market efficiency: evidence from European real estate securities futures, Journal of Real Estate Finance and Economics 48(2): 229-322. http://dx.doi.org/10.1007/s11146-012-9399-3

Lee, M.-L.; Chiang, K. 2010. Long-run price behaviour of equity REITs: become more like common stocks after the early 1990s?, Journal of Property Investment \& Finance 28(6): 454-465. http://dx.doi.org/10.1108/14635781011080302

Lee, M. L.; Lee, M. T.; Chiang, K. C. H. 2008. Real estate risk exposure of equity real estate investment trusts, Journal of Real Estate Finance and Economics 36(2): 165-181. http://dx.doi.org/10.1007/s11146-007-9058-2

Lehman, R. W.; Roth, H. S. 2010. Global real estate investment trust report 2010: against all odds. London: Ernst \& Young, 1-72.

Liow, K. H.; Newell, G. 2012. Investment dynamics of the greater China securitized real estate markets, Journal of Real Estate Research 34(3): 399-428.

Mcmillan, D. G.; Ulku, N. 2009. Persistent mispricing in a recently opened emerging index futures market: arbitrageurs invited, Journal of Futures Markets 29(3): 218-243. http://dx.doi.org/10.1002/fut.20355

Newell, G. 2005. Factors influencing the performance of listed property trusts, Pacific Rim Property Research Journal 11(2): 211-227. http://dx.doi.org/10.1080/14445921.2005.11104183

Newell, G. 2010. The effectiveness of A-REIT futures as a risk management strategy in the global financial crisis, Pacific Rim Property Research Journal 16(3): 339-357.

http://dx.doi.org/10.1080/14445921.2010.11104308 
Newell, G.; Acheampong, P. 2001. The dynamics of the Australian property trust market risk and correlation profile, Pacific Rim Property Research Journal 7(4): 259-270.

http://dx.doi.org/10.1080/14445921.2001.11104108

Newell, G.; Tan, Y. K. 2004. The development and performance of listed property trust futures, Pacific Rim Property Research Journal 10(2): 132-145. http:// dx.doi.org/10.1080/14445921.2004.11104157

Peterson, J. D.; Hsieh, C. H. 1997. Do common risk factors in the returns on stocks and bonds explain returns on REITs?, Real Estate Economics 25(2): 321-345. http://dx.doi.org/10.1111/1540-6229.00717

Pizzi, M.; Economopoulos, A. J.; O’Neill, H. M. 1998. An examination of the relationship between stock index cash and futures markets: a cointegration approach, Journal of Futures Markets 18(3): 297-305. http://dx.doi.org/10.1002/(SICI)10969934(199805)18:3<297::AID-FUT4>3.0.CO;2-3

Property Investment Research. 2012. Australian property funds industry survey 2012. Sydney: Property Investment Research.

Quan, J. 1992. Two-step testing procedure for price discovery role of futures prices, Journal of Futures Markets 12(2): 139-149. http://dx.doi.org/10.1002/fut.3990120203

Rosenberg, J.; Traub, L. 2007. Price discovery in the foreign currency futures and spot market. FRB of New York Staff Report. Federal Reserve Bank of New York.

Ryoo, H.-J.; Smith, G. 2004. The impact of stock index futures on the Korean stock market, Applied Financial Economics 14(4): 243-251. http://dx.doi.org/10.1080/0960310042000201183

Tornell, A.; Yuan, C. 2012. Speculation and hedging in the currency futures markets: are they informative to the spot exchange rates, Journal of Futures Markets 32(2): 122-151. http://dx.doi.org/10.1002/fut.20511
Tse, Y. 1999. Price discovery and volatility spillovers in the DJIA index and futures markets, Journal of Futures Markets 19(8): 911-930. http://dx.doi. org/10.1002/(SICI)1096-9934(199912)19:8<911::AIDFUT4>3.0.CO;2-Q

Tse, Y.; Xiang, J.; Fung, J. K. W. 2006. Price discovery in the foreign exchange futures market, Journal of Futures Markets 26(11): 1131-1143. http://dx.doi.org/10.1002/fut.20229

Wahab, M.; Lashgari, M. 1993. Price dynamics and error correction in stock index and stock index futures markets: a cointegration approach, Journal of Futures Markets 13(7): 711-742. http://dx.doi.org/10.1002/fut.3990130702

Xiang, V.; Fang, V.; Chng, M. 2013. Transmigration across price discovery categories: evidence from the U.S. CDS and equity markets, Journal of Futures Markets 33(6): 573-599. http://dx.doi.org/10.1002/fut.21599

Yang, J.; Bessler, D. A.; Leatham, D. J. 2001. Asset storability and price discovery in commodity futures markets: a new look, Journal of Futures Markets 21(3): 279-300. http://dx.doi.org/10.1002/10969934(200103)21:3<279::AID-FUT5>3.0.CO;2-L

Yang, J.; Zhou, Y.; Leung, W. K. 2012. Asymmetric correlation and volatility dynamics among stock, bond, and securitized real estate markets, Journal of Real Estate Finance and Economics 45(2): 491-521. http:// dx.doi.org/10.1007/s11146-010-9265-0

Yunus, N.; Hansz, J. A.; Kennedy, P. J. 2012. Dynamic interactions between private and public real estate markets: some international evidence, Journal of Real Estate Finance and Economics 45: 1021-1040. http://dx.doi.org/10.1007/s11146-010-9297-5

Zhong, M.; Darrat, A. F.; Otero, R. 2004. Price discovery and volatility spillovers in index futures markets: some evidence from Mexico, Journal of Banking and Finance 28: 3037-3054. http://dx.doi.org/10.1016/j.jbankfin.2004.05.001 